\title{
Turcizmi u časopisu Kršćanska obitelj (1900. - 1904.)
}

DRAŽENKO TOMIĆ

Sveučilište u Zagrebu

Učiteljski fakultet

E-pošta: drazenko.tomic@ufzg.hr
UDK: 811.163.42'373.45

008(497.6)"1900/1904"

Pregledni rad

Primljeno: 25. listopada 2018.

Prihvaćeno: 9. travnja 2019.

\section{Sažetak}

Turcizmi - riječi turskoga, arapskoga, perzijskoga i grčkoga podrijetla, orijentalizmi - prisutni su u hrvatskim (posebno štokavskim) govorima kao posljedica geografskih, povijesnih i kulturoloških dodira s turskim jezikom. Rad prije svega promatra danas manje frekventne, pa i sasvim arhaične turcizme i egzotizme, koji su bili u uporabi među katoličkim seoskim pučanstvom na početku dvadesetoga stoljeća. Ogledni primjerak je bosanskohercegovački, mostarski, mjesečnik Kršćanska obitelj, poučni i zabavni list za hrvatski katolički puk, a ujedno i glasilo hrvatskih seljačkih škola, koji su uređivali i tiskali hercegovački franjevci (1900. - 1920., 1938. - 1944.). Sa stajališta lingvističkih istraživanja valja ukazati na činjenicu da ovaj časopis počinje izlaziti dvadesetak godina nakon što je Austro-Ugarska zaposjela Bosnu i Hercegovinu (1878.) i da se ovdje promatra prvo petogodište časopisa, tj. dok ga uređuje Radoslav Glavaš, st. (1867. - 1913.). Turcizmi se najviše pojavljuju u pripovijetkama iz života na selu. Pronađeno ih je 167 i nekolicina riječi za koje nije sigurno podrijetlo, što je s ponavljanjima do najviše $0,05 \%$ ukupnoga broja svih riječi u časopisu. $S$ obzirom na vrstu riječi, prevladavaju imenice (88\%), a s obzirom na materiju na koju se odnose, pre- 
težno su riječi vezane uza stanovanje i privredu (21\%), vojsku i administraciju (18\%) te različite apstraktne riječi (37\%). Sama prisutnost tuđica u časopisu pokazuje kako uredništvo jeziku ne pristupa čistunski, a njihova nevelika brojnost i uz riječ napisan i prijevod upućuju na svijest urednika da su to ipak strane riječi.

Ključne riječi: hrvatski jezik; turcizmi; štokavsko narječje; $K r$ šćanska obitelj.

\section{Uvod}

Jezičnom posuđivanju doprinose izvanjezični (fizički i kulturni kontakti između govornika dvaju jezika - pa u tom slučaju supostoje i domaća i strana riječ) i unutarjezični razlozi (leksičke praznine, tj. nepostojanje leksema za neki segment izvanjezične zbilje). U našemu slučaju, višestoljetna izloženost turskome jeziku, religijski razlozi, pa i izostanak izravnoga administrativnog nametanja toga jezika (za razliku npr. od mađarizacije i germanizacije u sjeverno-hrvatskim krajevima) rezultirali su brojnim orijentalizmima, posebno u svim štokavskim govorima. ${ }^{1}$

U ovome radu koristi se termin turcizam - kao kulturno-povijesni i civilizacijski pojam - nerijetko se govori i o orijentalizmima, terminu koji se također rabi u lingvističkoj praksi. Namjera je dati do znanja da turcizmi nisu samo turske riječi nego i arapske, perzijske, mongolske, grčke i druge, a dio tuđica iz spomenutih jezika zaživio je na ovim prostorima i prije osmanlijskih osvajanja. Te riječi orijentalnoga kulturnog konteksta, prilagođene pravilima turskoga jezika,

1 Jedan od rijetkih kulturnih pregaoca koji se zalagao protiv turcizama bio je Matija Antun Relković (1732. - 1798.) slavonski jezikoslovac, književnik i prosvjetitelj. Njegov središnji spjev je Satir iliti divji čovik (1762.) u kojem, u popularnom obliku, donosi moralne pouke i pragmatične savjete za gospodarsku i duhovnu obnovu zemlje te između ostaloga i stav o turskom jezičnom naslijeđu. Ekrem Čaušević, "Turci u Satiru Matije Antuna Relkovića", Prilozi za orijentalnu filologiju, 47-48, 1999., str. 67-84; EKREM ČAUšEvić, "Turkološke marginalije o Relkovićevu Satiru", u: Matija Antun Relković i Slavonija 18. stoljeća, radovi sa znanstvenog skupa u povodu 200. godišnjice smrti [ur. Dunja Fališevac], Zagreb - Davor, Poglavarstvo općine Davor - Filozofski fakultet, 2000., str. 233-243. 
bivaju posredovane turskim jezikom drugim narodima gdje se opet modificiraju u skladu s pravilima dotičnoga jezika.

Kao izvor turcizama u vrijeme njihova posuđivanja poslužili su rumelijski dijalekti turskoga jezika iz 15. st., a koji se razlikuju od maloazijskih dijalekata na temelju kojih je izgrađen suvremeni turski standard (ponajviše je prisutan istanbulski govor anadolijskoga dijalekta). Otud je dosta teško istraživati semantičke pomake (derogacija, amelioracija, suženje i proširenje značenja) koji se redovito događaju u semantičkom jezičnom posuđivanju jer gotovo da nije poznato da postoji naš stručnjak koji bi dobro poznavao taj stari turski dijalekt i koji bi mogao raditi takva istraživanja. No na jednaku poteškoću nailaze sva istraživanja koja se bave dijakronijskim semantičkim pomacima. $^{2}$

Tragovi interferencije turskoga i hrvatskoga jezika prisutni su na leksičkoj razini hrvatskoga jezika, ali bilo je utjecaja i na fonološkoj i na tvorbenoj razini. Na fonološkoj razini turcizmi su potpomogli učvršćivanju glasova $f, h, d \check{z}$ u hrvatski fonološki sustav. Sama fonološka prilagodba turcizama nije bila teška jer turski jezik ima 29 fonema. ${ }^{3}$ Na tvorbenoj razini pojavilo se nekoliko produktivnih sufiksa: -lija (Sarajlija, Maglajlija), -li (obrazli, merakli, rahmetli), -luk (bezobrazluk, pasjaluk), -džija (buregdžija, provodadžija, bundžija, samardžija) i drugi. ${ }^{4} \mathrm{Na}$ morfološki i sintaktički ustroj hrvatskoga jezika turski jezik nije značajno djelovao zbog tipološke razlike tih dvaju jezika: turski je u skupini aglutinativnih jezika, a hrvatski u skupini flektivnih jezika.

Uza spomenuto, Osmanlije donose sa sobom i brojne izvanjezične realije nepoznate domaćem stanovništvu. Vidljivo je to posebice u islamskoj kulturi i religiji (džamija, imam, ulema, Bajram), kulinarstvu (ćevap, sarma, pita, rahatlokum, baklava) i vojnoj terminologiji (top, bedem, barut). Mnogi turcizmi su ili potisnuli stare slavenske riječi, germanizme ili neke staroromanske europeizme ili su ravnopravni s njima. Vrljić navodi Pranjkovićevo mišljenje da u hrvatsko-

2 Iako su preuzete od Osmanlija, zbog razvoja jezika, današnji Turci ih ne koriste (peškir, npr.). O tom, npr. EкREM ČaušEvić, "The Turkish Language in Ottoman Bosnia", The Isis Press, Istanbul, 2014., str. 248.

3 Josip Ваотіс́, "Orijentalizmi u govoru starosjedilaca Bosanske Posavine", u: Književni jezik, 23, Sarajevo, 2012., str. 50-64 (52).

4 Stojan Vrluić, "Prijevodni ekvivalenti hrvatskih turcizama u njemačkom i ruskom jeziku", u: Filologija, 38-39, Zagreb, 2002., str. 275-286 (275). 
me jeziku ima oko deset tisuća orijentalizama, ${ }^{5}$ dok ih je za usporedbu u poljskom jeziku samo tridesetak. ${ }^{6}$

Turcizmi se dobro čuvaju u mnogim frazemima raširenima po cijelom području hrvatskoga jezika. Kako za frazeme vrijedi pravilo da su njihove sastavnice nepromjenjive, stilska obilježenost turcizma tu nimalo ne smeta. Vranić i Zupčić donose popis takvih frazema koji su prisutni ne samo u štokavskom, nego i u čakavskom i kajkavskom narječju, kao: Ni mi po čefu (kajk.), Biti pun para, Nije beg cicija. (čak.), Odrišit kesu (čak.), Pripovedati Markove konake (kajk.), Pušiti kak Čifut ${ }^{7}$ (kajk.). ${ }^{8}$ U kajkavskom narječju očuvao se npr. turcizam tabor u značenju rat. Stariji stanovnici i ne govore drugačije nego tako. ${ }^{9}$

Valja napomenuti da su mnogi turcizmi koji su dio norme srpskoga i bošnjačkoga standardnog jezika u hrvatskome jeziku stilistički obojene riječi i služe za modalnu jezičnu uporabu, a posebice u nekim štokavskim područjima, kao npr.: komšija, pare, sokak, džukela, dubre, džumbus, fukara ${ }^{10}$ i druge... Takvih je stilski obojenih riječi znatno više u srpskome jeziku (npr. burazer). Kod muslimanskoga stanovništva mnogo turcizama koristi se za terminologiju srodstva (amidža / stric, daidža / ujak, teza / teta, babo / otac, inđa / zaova i drugi), ${ }^{11}$ ali

5 S. VRljić, nav. dj., str. 275 prema: Ivo Pranjković, "Hrvatski u kontaktu s orijentalnim jezicima", u: Behar, Zagreb, 1992.

6 Arbuz "lubenica", bakalie "poslastic", bazar, buzdygan "buzdovan", chałwa "alva", cybuch "plamenik", czaprak "sedlo", dywan, haracz, horda, jogurt, jasyr "ropstvo", jarmułka "kapica", kaftan, kawa, kawior "kavijar", kobierzec "tepih", kołpak, kołczan "tobolac", makata "tapiserija", ogier "ždrijebac", surma "truba", tabun "stado", torba, turban, tytoń "duhan". STANISLAV STACHOvsкy, Fonetyka zapozyczen osmansko-tureckich w jezyku serbsko-chowrackim, Ossolineum, Wroclav, 1973.

7 U ispitanim kajkavskim govorima Čifut nije pogrdan naziv za Židova, nego znači Turčin. Đuro BlažEKA, Rječnik preloške skupine govora međimurskoga dijalekta, Učiteljski fakultet, Zagreb, 2018.

8 Silvana Vranić - Sanja Zubčić, "Turcizmi u frazemima hrvatskih govora", u: Filologija, 60, Zagreb, 2013., str. 103-145.

9 Đ. BLAžEKA, Rječnik preloške skupine..., str. 712.

10 Posuđenica se udomaćila u hrvatskome jeziku (roman Ivana Aralice) zbog poklapanja korijena riječi s poznatim vulgarizmom i njegovim različitim konotacijama. U turskom jeziku radi se samo o sirotinji.

11 Iscrpan rad o toj temi: Marta Bjeletić, "Turcizmi u srpskohrvatskoj terminologiji srodstva", u: Južnoslavenski filolog, 51, Zagreb, 1995., str. 203-221. 
i na komunikaciju i priložnu uporabu. ${ }^{12}$ Općenito, velik broj turcizama lokalizama je izgubljen.

Autor je rezultate istraživanja u prvim trima godištima časopisa $\mathrm{Kr}$ śćanska obitelj izložio u radu "Turkish Loan Words in the BosnianHerzegovinian Magazine 'Kršćanska obitelj' (1900. - 1902.)" na 13th International Balkan Education and Science Congress, 6.-8. 9. 2018., Edirne (Turska). Metodologija, razrada i zaključak objavljeni su u pripadajućem zborniku kongresa (7,6 kartica teksta). Zatim je istraživanje prošireno na još dva godišta časopisa kako bi se obuhvatila godišta koja je uređivao Radoslav Glavaš (1900. - 1904.). Na stručnoj i znanstvenoj pomoći u oblikovanju ove znatno proširene verzije rada autor zahvaljuje prof. dr. Đuri Blažeki, hrvatskome dijalektologu.

\section{2. Časopis Kršćanska obitelj}

Kršćanska obitelj, poučni i zabavni listza hrvatski katolički puk. Izdaju učitelji franjevačkog bogoslovnog sjemeništa. Izlazi 10. svakog mjeseca, ciena na godinu 3 krune, tekst je koji stoji na naslovnici svakoga broja ovoga mjesečnika u prvom periodu njegova izlaženja. Od 1916. godine Kršćanska obitelj postaje službeno glasilo hrvatskih seljačkih škola pod nadzorom hercegovačkih franjevaca ${ }^{13}$ pa list ubuduće prati rad seljačkih škola i podupire ih, donoseći izvješća o njihovu stanju i podatke o njihovu napretku, ali i smjernice za učinkovitije djelovan-

12 Đuro Blažeka pronalazi mnogo takvih turcizama u govorima sjeverozapadne Bosne. Iz još neobjavljenoga rada dozvolom istraživača ovdje se navode tri priloga koji se odnose na lagano ograđivanje od vjerojatnosti da je istina ono što se govori:

- àsle $a d v . z a i s t a ;$ vjerojatno: Ma čüla sam jâ tô òdnjekud, àsle si mi tî tô rëko?

- kuđója adv. navodno, tobože: Öna je kuđója zavŕšila njëkve škôle, al je 1 to ǐšta - nije nïšta.

- zórli $a d v$. doista, s velikim intenzitetom: Vàni je zórli lèdeno, zavéži štà oko kŕsta.

Vrijedan je i Baotićev spomenuti dijalektološki rad iz 2007. gdje govori o orijentalizmima u govorima starosjedilaca bosanske Posavine. U tom istraživanju autor je pronašao velik broj turcizama koji su u tom dijalektu doživjeli fonološke i semantičke promjene svih vrsta u odnosu na one oblike i značenja koja se smatraju uobičajenima u dosadašnjoj literaturi.

13 "Hercegovački provincijal O. fra David Nevistić o našem listu", u: Kršćanska obitelj, god. 17, br. 12, Mostar, 1916., str. 283-286. 
je. U prvom broju zacrtani pravac Kršćanska obitelj zadržala je sve do zadnjeg broja (studeni, 1944.). ${ }^{14}$

Mjesečnik Kršćanska obitelj izlazio je od 1900. (I.) do 1920. (XXI.*) i od 1938. (XXI.) do 1944. (XXVII.) godine i tiskan je u Mostaru u franjevačkoj Hrvatskoj dioničkoj tiskari. U 27(28) godišta izlaženja objavljeno je 9.094 različite jedinice ( 337 po godištu, 28 po broju) na 6.751 stranici (bez omota). Uzimajući u obzir da je dio njih objavljivan u nastavcima, ukupno je objavljeno oko 10.500 jedinica (388 po godištu, 32,5 po broju). List je zaključivan većinom od 23. do 26. dana u mjesecu. Otisnut je crnom tintom postojane kvalitete, a iznimno u svečarskim prigodama javlja se i tisak u boji. Tekst je složen u dva stupca. Rubrike koje sadrže vijesti i umjetničke osvrte tiskane su sitnijim i gušće složenim slovima. Papir je nešto lošije kvalitete tijekom Prvoga svjetskog rata. Starija godišta (do 1920.) otisnuta su na ukupno 4.604 stranice, koje je najviše uređivao A. Majić 1.344 (29\%), potom V. Vasilj 1.180 (26 \%), R. Glavaš 1.092 (24\%), S. Musić 792 (17 \%) i D. Nevistić 196 (4 \%) stranica. Dimenzije ovih godišta Kršćanske obitelji su $24,7 \times 17 \mathrm{~cm}$.

Promidžba Kršćanske obitelji obavljala se na razne načine. Prvi broj svakoga godišta slan je na različite adrese, pa ako se on ne bi vratio uredništvu, nastavilo se slati i druge brojeve. Zatim, sigurno najučinkovitiji način je bio raspačavanje lista preko župnih ureda i škola. Uredništvo nastoji potaknuti župnike da se učinkovitije odazovu pozivu za nalaženjem što više pretplatnika. Konačno, po različitim naseljima postojali su i povjerenici koji bi nalazili pretplatnike i raspačavali list. List se financirao pretplatom i, kako to obično biva, imao je problema s naplatom pretplate. Stalno inzistiranje urednika na pretplati potaknuto je prije svega dugovanjima koje je Kršćanska obitelj imala kod Hrvatske dioničke tiskare kojoj je uprava Lista usluge plaćala mjesečno (barem poslije 1912. godine). List je jedno vrijeme donosio plaćene oglase. Moguće da je izlaženje lista sufinancirala uprava Hercegovačke franjevačke provincije.

Urednici su svjesni da se najveći broj čitatelja regrutira iz seljačkoga staleža, pa stavljaju naglasak na odgoj i obitelj, koji su opet povezani s nacionalnom i vjerskom pripadnošću. Takva orijentacija časopisa diktira njegov sadržaj: nagovori, primjeri, pjesme, pripovijetke i vijes-

14 DražEnko Tomić, Kršćanska obitelj, sv. 1, Franjevačka knjižnica i arhiv, Mostar, 2001. 
ti. Tri četvrtine građe u Kršćanskoj obitelji čine društvene znanosti $(26,3 \%)$, religija (24,3 \%) i književnost (23,3\%). Oko 8 \% ukupnoga materijala su pripovijetke, ali zanimljivo da niti jedna nije napisana na ikavici. Najčešće spominjani toponim je Mostar (čak petina svih spomenutih). Kršćanska obitelj obiluje izvanrednim književnim djelima, te nekim aktualnim informacijama, ipak se uočava nedostatak ilustracija. Kršćanska obitelj u prvom vremenu izlaženja ima 126 različitih ilustracija. To su 6,3 ilustracija po godištu ( 0,5 po broju) dok kasnija Kršćanska obitelj ima u prosjeku deset puta više ilustracija.

Sagledavajući jezik Kršćanske obitelji, bitno je spomenuti činjenicu da su Kršćansku obitelj uređivali i većinu priloga pisali profesori bogoslovnoga učilišta u Mostaru. Svi su oni nastojali što bolje njegovati hrvatski jezik. Na više mjesta napominju da dopisničke priloge prepravljaju i prilagođuju suvremenim pravopisnim normama, izuzev ako je autor inzistirao da jezik ostane nepromijenjen. U prvom periodu izlaženja Kršćanske obitelji uočavamo kako izostaje pisanje jata kao ije, taj se dvoglas piše kao ie (vrieme, ciena). Vidimo da pravopis naginje korijenskom načelu, npr. sdušno, ženitba. Za fonem $d$ upotrebljava se digram $g j$ (megju = među). Grafem $d$ se prvi put javlja 1917. godine u imenu Đuro Damaska. ${ }^{15}$ Promjene u pravopisu mogu se pratiti i u imenima rubrika: rubrika Viestnik od 1910. postaje Vijesnik, da bi 1914. godine u 1(XV.) postala Vjesnik. Veliku jezičnu promjenu učinio je urednik A. Marić nakon jezične reforme koju je provela Zemaljska vlada $\mathrm{BiH} 1912$. godine. ${ }^{16}$

Prvi urednik časopisa Kršćanska obitelj bio je o. fra Radoslav Glavaš st. (Drinovci, 28. 11. 1867. - Humac, 20. 7. 1913.). Studirao je teologiju u Italiji i Austriji. Predavao je dogmatiku na teologiji u Mostaru, bio biskupov tajnik i kapitularni vikar Mostarske biskupije. Napisao je nekoliko knjiga i surađivao u brojnim časopisima. Kršćansku obitelj uređivao je od 1900. do 1904. Imajući pred očima vrlo visok postotak nepismenih nastoji "... list tako udesiti kako u rasporedu tako i u rasponu štiva da bi što više koristio jednostavnom [tj. priprostom] puku. ${ }^{17}$ Osmislio je koncepciju lista koja će gotovo nepromijenjena

15 "Akademičko sijelo zbora franj. bogoslova 'Bakule' u Mostaru", u: Kršćanska obitelj, god. 18, br. 1-2, Mostar, 1917., str. 24.

16 "Nešto o pravopisu u hrvatskom jeziku", u: Kršćanska obitelj, god. 13, br. 11, Mostar, 1912., str. 259.

17 "Prijateljim na molbu i uvaženje", u: Kršćanska obitelj, god. 1, br. 2, Mostar, 1900., str. 34. 
ostati do 1920. godine. U Glavaševoj Kršćanskoj obitelji formativni prilozi slijede katoličko učenje, ne nedostaju crtice iz života katoličkih svetaca, pripovijetke imaju izrazitu moralnu poruku, u svakom broju pojavljuje se pokoja pjesma, gotovo da nema slagarskih pogrješaka. Nedostatci se uočavaju prije svega u "Viestniku": gotovo da nema vijesti iz Hercegovine - izuzev možda vijesti o biskupu fra Paškalu Buconjiću - a opet gotovo u svakom broju pojavljuju se vijesti iz svijeta, a posebno događanja u svezi progona katolika u Francuskoj. Ilustracije su vrlo rijetke.

Glavaš dosljedno provodi jezično-pravopisna pravila svoga vremena. Koliko je u tom bio dosljedan pokazuje i osvrt Veljka Obradova na Glavaševu knjigu Život i rad fra Rafe Barišića (1900.): "... sve liepo okitio u knjigu, čistim hrvatskim jezikom začinio, da je milota čitati. U nas se danas piše svakako, nateže se s našim milim jezikom i tamo i amo. A fra Radoslav je napisao ovu knjigu onakvim živim i čistim jezikom kao što se može samo u nas, u Hercegovini naći, koji nismo natrunjeni još tuđinštinom [vjerojatno germanizmima]." Rečeno se može vidjeti i u Glavaševu nastupnom članku u prvom broju prvoga godišta časopisa (uz opasku da u njemu na dva mjesta nalazimo glagol "nijetiti"). ${ }^{18}$

Kako doznajemo iz časopisa, urednik Glavaš u prosincu 1904. pobolijevao je pa je zbog toga prosinački broj kasnio. Uredništvo priopćava da je dotadašnji urednik zbog drugih dužnosti (tajnik biskupa Buconjića) uređivanje lista prepustio fra Davidu Nevistiću. ${ }^{19}$ On uređuje samo jedno godište (1905.) i u potpunosti slijedi Glavaševu koncepciju lista, s manjim promjenama u rubrikama časopisa i nešto više vijesti o događanjima u Hercegovini.

U Kršćanskoj obitelji ovdje izloženi turcizmi povezani su s katoličkim seoskim življem. Valja uz ovo spomenuti i pretežno blagonaklon stav uredništva Kršćanske obitelji prema muslimanima. Taj stav je osjetan u osvrtu Antuna Hangija na knjigu Život i običaji Muslimana u Bosni i Hercegovini (Mostar, 1900.) tiskane upravo u nakladi franjevačke tiskare:

[To je knjiga] ... koja se bavi životom i običajim naše po krvi braće muslimana... Treba priznati istinu, da medju mnogim, izvan Bosne

18 Radoslav, Glavaš, "Naš zadatak u sadanje vrieme", u: Kršćanska obitelj, god. 1, br. 1, Mostar, 1900., str. 2-7.

19 "Našim čitateljim", u: Kršćanska obitelj, god. 5, br. 12, Mostar, 1904., str. 200. 
i Hercegovine, vladaju i sada mnoge presude proti nama Bošnjacim $i$ Hercegovcim, osobito proti našim muslimanim, što je sve na štetu naše narodne hrvatske stvari, a možemo stalno reći i naše katoličke vjere, jer se time stavljaju velike zaprieke modjusobnom približivanju. Kućni $i$ domaći život $i$ običaji naših muslimana jesu u svojoj suštini stari hrvatski običaji, istina, [pod] uplivom islama, kao što i kod kršćana [pod] uplivom kršćanstva, u mnogo čem preinačeni. I danas možda, da se nigdje niesu tako čisto sačuvali stari hrvatski običaji kao u begovskim kućam. Ova će knjiga mnogo doprinieti, da panu mnoge prosude, da se jednoplemena braća bolje upoznadu, i medjusobno se uzljube, te zajednički uzrade na dobro naše mile domovine Hrvatske. ${ }^{20}$

\section{Metodološka polazišta u leksikografskome opisu turciza- ma iz časopisa Kršćanska obitelj}

U ovome istraživanju nisu obuhvaćene riječi koje su se u potpunosti udomaćile u standardnome jeziku (usvojenice, poput čarapa, bubreg, čamac, ćelav, čekić, mušterija), nego manje frekventni turcizmi koji su vezani za pojedina narječja ili pokrajine, npr. taze, fišek, hava, harman, insan, haber, i druge, što je Škaljićeva četvrta skupina turcizama. ${ }^{21}$

U članku navedeni turcizmi izdvojeni su pomnim čitanjem tekstova. Moguće da je pri tom poslu neka riječ preskočena. Nije posebno bilježena učestalost pojavljivanja turcizama u tekstovima, nego su uvijek bilježeni novi turcizmi. Uza svaku riječ nalazi se i popratni tekst kao i mjesto gdje je riječ pronađena: godište, broj i stranica. Popratni tekst nije svaki put preuzet s mjesta gdje se dotični turcizam prvi put pojavio, nego s mjesta čiji popratni tekst najbolje tumači značenje turcizma, uz nastojanje da tekstovi budu što raznolikiji.

Natuknički se leksemi bilježe u kanonskom (citatskom) obliku: imenice $u$ nominativu jednine, glagoli $u$ infinitivu...), i onda kada se u tekstu ne nalaze u tim oblicima. Riječ je pisana onako kako se bilježi

20 "Život i običaji Muslimana u Bosni i Hercegovini", u: Kršćanska obitelj, god. 2, br. 3, Mostar, 1901., str. 63; sličan zanos prisutan je i u povelikom osvrtu na knjigu Hrvatske narodne ženske pjesme (muslimanske) Mehmeda Dželaludina Kurta. - r -, "Hrvatske narodne ženske pjesme (muslimanske)", u: Kršćanska obitelj, god. 4, br. 1, Mostar, 1903., str. 14.

21 Aвdulah Škaljić, Turcizmi u srpskohrvatskom jeziku, Svjetlost, Sarajevo, 1985., str. 16. 
u rječniku, ali nije pisan naglasak riječi. U popratnom tekstu vidi se izvorni oblik riječi. Značenje riječi uglavnom je navedeno prema Anićevu Rječniku (1991.), a ako riječi tamo nema, onda prema Škaljiću (1985.) te nekoliko riječi prema Klaiću (1990.). ${ }^{22}$ Prema Klaiću navedeni su izvorni (turski i drugi) oblici riječi. Izdvojene su i neke riječi koje nisu zabilježene u trima odabranim jednojezičnim rječnicima. ${ }^{23}$

22 Vladimir Anić, Rječnik hrvatskoga jezika, Novi liber, Zagreb, 1991.; BratoLJUB KLAIĆ, Rječnik stranih riječi, Nakladni zavod Matice hrvatske, Zagreb, 1990. Još treba spomenuti i Rječnik posuđenica iz turskog jezika Milana Nosića (Maveda, Rijeka, 2005.) koji u ovom radu nije iscrpnije konzultiran, ali i čitav niz s ovom temom povezanih članaka. Ivan EsıH, Turcizmi, rječnik turskih, arapskih $i$ perzijskih riječi u hrvatskom književnom jeziku i pučkom govoru s pregledom nove turske abecede i slovnice, Vlastita naklada, Zagreb, 1942. (pretisak: Ex libris, Zagreb, 2010.); EKrEM ČAUŠEvić, "Türkische Sprichwörter aus Bosnien (Turkish Proverbs from Bosnia)", u: Materialia Turcica, 19, 1998., str. 63-68; EKREM ČAUšEvić, "Miloš Mandić i njegov rječnik turcizama (o prvome rječniku turcizama u povijesti turkologije)", u: Hrvatska i Turska. Povijesnokulturni pregled [ur. Katica Jurčević - Ozana Ramljak - Zlatko Hasanbegović], Srednja Europa - Institut društvenih znanosti Ivo Pilar, Zagreb, 2016., str. 8592; IRINA BUDIMIR, Leksik hercegovačke periodike na prijelazu iz XIX. u XX. st. Doktorski rad, Filozofski fakultet Sveučilišta u Zagrebu, Zagreb, 2014.; MARTA ANDRIĆ, "Turcizmi u seoskom govoru Slavonije", u: Migracijske i etničke teme, 19, 2003., 1, str. 17-27; Dalibor BulJan-KlaPIRIĆ, Turcizmi u govoru i narodnim pjesmama Imotske krajine, Udruga "Raosovi dani", Imotski, 2001.

23 ČEVT $m$ kraj - ... putnici, prosjaci, i svak znade za Jozinu kuću, a kako i ne će, ta nema je sjegurnije na našemu čevtu (kraju). (II,9,177); ĆERA ž boja lica - ... svakomu se čini, spava, ni malo mu se nije promienula ćera. (II,4,87); ĆERUBAH $m$ - ... a lijevom rukom igraše se jednom krugljom od finog jantara (ćerubaha). (II,4,76); ĆIRPo $m$ golać - Vazda sam bio jedan ćirpo. (II,5,103); HREK $m$ panj - gorućega hreka (II,10,193), poštenoga hreka (III,2,40); MOLUć $m$ Sam naš car ima kabanicu, a svi ostali kukuljicu, pa da se oni kozar, jadna im majka, s molućem (velikom vlasti) izbiju. Mislio i Moskov našega cara dobiti, al je pokusao pilav, kad mu nije bio još varen!!! (II,10,197); NASPLOH pril. neprestano - Ali našem je milokrvnom gazdi jadno to zdravkanje i živkanje, jer je nasploh postavao razdraženiji, tuplji i nesnosniji. (I,8,157); PEDIPSATI mučiti - Stavljan u haps i na različite načine pedipsan. (III,4,64), Pedipsat ih... (III,1,4-6); PEŠTER $m$ pećina - Ništa mu nije išlo za rukom, ipak n[ij]e htio uvidjeti, da je tu prst božji zbog njegove dobre i plemenite supruge. S peštera je u pešter jurio. Ona je počela osjećati oskudicu... (III,12,207); PLAHo pril. velikim intenzitetom - Prisutni se presenetili, slušajuć takvu molitvu, a prenuli od straha, kad je ustao Petar i rekao im, da ga je plaho zaboljela glava, a to baš dopuštenjem božjim istina bila. (II,5,105); ŠKAMBAs $m$ vrsta drvene posude Masla pritopna u škambasu... (III,2,37); токоRsEm pril. na silu - Bjehu me tokorsem na nekoliko mjeseci spremili u višu školu, ali nesreća htjede, pa ne ostah u njoj evo ni punu godinu dana, nego moradoh započete nauke prekinuti. 
U zagradama zbog lakšega čitanja teksta pretežno donosimo samo ono značenje iz leksikografske literature koje je potvrđeno u priloženom tekstu.

\section{Analiza turcizama u Kršćanskoj obitelji}

Pregledano je prvih pet godišta časopisa, 1900. - 1904. U njima se nalazi 763 različita naslova (I. god. 163, II. god. 162, III. god. 156, IV. god. 133, V. god. 149) na 1092 stranice teksta (I. god. 236, II. god. 248, III. god. 216, IV. god. 192, V. god. 200) s cca. 529.900 riječi (I. god. 115.000, II. god. 121.000, III. god. 107.000, IV. god. 90.000, V. god. 96.900). Pronađeno je 167 različitih turcizama i nekolicina riječi za koje nije sigurno podrijetlo. To je $0,03 \%$ svih riječi u časopisu, a ako se uzmu u obzir i višestruka ponavljanja nekih riječi, moguće najviše oko $0,05 \%$. Značenje otprilike polovice riječi napisano je prema Anićevu rječniku, a ostatak prema Škaljićevu rječniku. Uz nekoliko iznimki, sve riječi se nalaze u Klaićevu rječniku.

Pronađeni turcizmi najviše se pojavljuju u pripovijetkama koje se bave zgodama iz života na selu, kao npr.: u 14 nastavaka pripovijetke Đure Džambasa "U tudju dobru dobra nije, pa sto ti zapisa", u 8 nastavaka niza "Rane obitelji" i u drugim pripovijetkama, njih ukupno 43 pripovijetke u prva tri godišta časopisa (1900. - 1902.). Veljko Obradov (Ante Jukić) u istim godištima u 6 svojih pjesama ima pokoju takvu riječ, ali i u 4 pjesme drugih autora. Petnaest članaka sadrži te riječi, kao i 9 različitih vijesti. U naknadno obrađenom četvrtom i petom godištu (1903. i 1904.) turcizama je znatno manje, pa i onih čija je učestalost pojavljivanja u prošlim godištima bila nešto veća. Razlog tomu je što četvrto i peto godište gotovo niti nemaju pripovijetke s hercegovačkoga sela. Valja istaknuti kako se dio turcizama iz četvrtoga godišta (1903.) pojavljuje u tekstu u nastavcima "Štiva iz sv. Pisma" autora I. Lekića gdje on prepričava poznatije zgode iz Staroga Zavjeta dodajući da radi prema "... najposljednjem prievodu Karadžića i Daničića..."24

(III,8,143); тUвок $m$ prvi grumeni tek zgrušenog mlijeka - Jutarnjega cida mlieka tubok. (II,11,213); USAPITI uspuhati, oznojiti - Majka i jedinica kći usapile se. (II,9,173); ZA UHAR dobro je, vrijedno je - ... nego da je posiedila jedino od brige za Vaš narod, i takodjer odlučena za dobro duhova, i za uhar crkvi. (III,5,91), Svaki njegov vjernik, kao i svaki Hrvat, zavapit će Bogu, da nam ga još dugo i dugo požive na uhar vjere i hrvatske domovine, kojem se uzkliku i mi iz srdca pridružujemo. (IV,5,78)

24 I. Lekić, "Štiva iz sv. Pisma", u: Kršćanska obitelj, god. 4, br. 1, Mostar, 1903., str. 5. 
Prema vrsti pronađeni turcizmi su pretežno imenice (47,88 \%). Imenice i druge vrste riječi sklanjaju se prema pravilima hrvatske gramatike. S obzirom na materiju na koju se odnose, riječi se mogu grupirati u skupine među kojima se ističu one koje su vezane uz građevine, kućni inventar, stočarstvo i zemljoradnju (35,21\%), vojne izraze i državnu administraciju (30,18\%), različite apstraktne riječi $(62,37 \%)$, i manje skupine riječi $(40,24 \%)$.

Škaljić upozorava da se nemuslimani, kad su u pitanju turcizmi, u izgovoru riječi znatnije od muslimana udaljavaju od izvorne riječi koja je preuzeta od Turaka ili preko Turaka, osobito u zamjeni $c$ i $c$, izgovoru glasa $h{ }^{25}$ i njegovoj hipertrofiji, kao npr.: "Iz dosada navedenoga jasno je, da to djelo pripomoći trpećim dušam u čistilištu, Bogu je vehoma ugodno, a i nam samim u velike koristno."26 "Hvala Bogu, nije mu onaj naduti poručnik ništa nahuditi mogao, jerbo je bio na sreću Ferdinu k drugoj regimenti premješten, te se je tako Ferdo pomoćju božjom riešio te sotone i hudobe." ${ }^{27}$ Udaljavanje od izvorne riječi tiče se ne samo oblika, nego i značenja riječi, pa i njihove učestalosti ovisno o bosansko-hercegovačkoj regiji u kojoj se koristi. Kod mnogih riječi došlo je do semantičkih pomaka, a često su značenja u rječnicima i drukčije opisana.

Turcizmi koji su pronađeni u Kršćanskoj obitelji ponekad imaju u zagradi napisan svoj ekvivalent na hrvatskome jeziku, kao što je čest slučaj u pripovijetki "U tudjem dobru dobra nije pa sto ti zapisa". Npr.: "Jozo se oslonio na Ivu, mladjega, ali i pametnijega, neka on sam čališi (nastoji) za obadvojicu, da čim prije zapise dobiju. ${ }^{28} \mathrm{U}$ nekim slučajevima turcizam se nalazi u zagradi, kao: "Donesite čvrsta platna (beza) i jamite voska..." ${ }^{29}$ (Ovdje je bez vrsta platna, a ne platno općenito.) Postoje slučajevi gdje se jedan turcizam tumači drugim, prisutnijim u govoru, kao: "Tko znade, čija će biti, a možda će je biti i za badavat (džaba), ako dodju Niemci." ${ }^{30}$

25 A. ŠKaljIĆ, Turcizmi u srpskohrvatskom jeziku, str. 20.

26 David Nevistić, "Dušni dan", u: Kršćanska obitelj, god. 5, br. 11, Mostar, 1904., str. 168.

27 S. M., "Uskrsna jaja", u: Kršćanska obitelj, god. 5, br. 2, Mostar, 1904., str. 28.

28 Gjuro DžAmbas, "U tudju dobru dobra nije, pa sto ti zapisa", u: Kršćanska obitelj, god. 3, br. 7, Mostar, 1902., str. 117.

29 Gj. Džambas, "U tudju dobru...", u: Kršćanska obitelj, god. 3, br. 4, Mostar, 1902., str. 70.

30 GJ. Džambas, "U tudju dobru...", u: Kršćanska obitelj, god. 2, br. 10, Mostar, 1901., str. 197. 
Ponegdje se posuđenica iz nekoga neorijentalnog jezika nastoji pretvoriti u orijentalizam. Tako, riječ arija (tal. zrak) piše se kao harija: "Nu nigdje ništa na ovom bielu svietu, do mojih deset nokata svega, a ti na najzadnjem času velišs, nati, pa odklen, zar iz harije božje?"31

\section{Zaključak}

Tijekom ovoga istraživanja pokazalo se kako prvo petogodište mjesečnika Kršćanska obitelj, urednika Radoslava Glavaša, sadrži nevelik broj turcizama, ostatak povijesne i prostorne izloženosti turskom jeziku. Te riječi, za koje je utvrđeno da su značenjski pretežno imenice i da su vezane uza stanovanje, vojsku, administraciju i različite apstraktne riječi, pojavljuju se najčešće u pripovijetkama kako bi se što vjernije oslikala atmosfera hercegovačkoga sela. Neke od njih su se i donedavno mogle čuti u govornom jeziku starijega hercegovačkog hrvatskog življa.

Prisutnost tuđica u časopisu Kršćanska obitelj upućuje na zaključak kako urednik i njegovo uredništvo (profesori bogoslovnoga učilišta u Mostaru) jeziku ne pristupaju čistunski, nego s nastojanjem da se riječ - pa bila ona i strana - upotrijebi primjereno okružju u kojem se rabi. S druge strane, nevelika brojnost spominjanih tuđica, kao i to što se nerijetko uz njih bilježi i adekvatna standardizirana zamjena (prijevod), upućuje na činjenicu kako su odgovorni u časopisu bili itekako svjesni da se radi upravo o stranim riječima koje, iako zanimljive pa i vrijedne u lokalnom govoru, nisu ono najvrjednije u tom govoru, nego tek odjek tragičnih povijesnih okolnosti.

31 Gj. Džambas, "U tudju dobru...", u: Kršćanska obitelj, god. 2, br. 5, Mostar, 1901., str. 103. 
DRAŽENKO TOMIĆ

\section{Turkish loan words in the magazine Kršćanska obitelj (1900 - 1904)}

\section{Summary}

Turkish loan words - the words of Turkish, Arab, Persian and Greek origin, i.e. orientalisms - are present in Croatian (especially Štokavian) speeches as a result of geographical, historical and cultural contacts with the Turkish language. The paper analyses today less frequent and quite archaic Turkish loan words and exoticisms that were used by Catholic village people at the beginning of the $20^{\text {th }}$ century. The sample copy for the research was the Bosnian-Herzegovinian, monthly magazine Kršćanska obitelj (Christian Family) from the city of Mostar, an educational and entertainment magazine for the Croatian Catholic people and a periodical of Croatian peasant schools that was edited and printed by the Herzegovinian Franciscans (1900 - 1920 and 1938 - 1944). From the point of view of the language research, it should be noted that the starting point of the publishing of this magazine dates back to twenty years after the beginning of the Austro-Hungarian occupation of Bosnia and Herzegovina (1878) and that paper analyses the first five years period of the publishing of the magazine, i.e. the period when it was edited by Radoslav Glavas, sr. (1867 - 1913). Most Turkish words appear in the stories of the village, a total of 167 words, what is $0.05 \%$ of the total number of words in the magazine. Regarding the word classes most of them are nouns $(88 \%)$ and regarding the matter words are mostly referred to buildings and economy (21\%), army and administration (18\%), and different abstract words (37\%). Turkish words in the magazine testify that the editor has a pluralistic spirit and their not insignificant number and translation written besides the word show that the editor knows that these are strange words.

Keywords: Croatian language; Turkish loan words; Štokavian dialect, Kršćanska obitelj (Christian Family). 


\section{Prilog: \\ Turcizmi zabilježeni u trima odabranim jednojezičnim rječnicima}

adet $m$ (tur. adet) običaj, navika, navada - Ilija, čovjek stara kova, držao se starinskog adeta, pa nije mario ni za kakve novotarije, te se je u njega skupilo sve što je pribrano i izabrano. $(\mathrm{I}, 7,137)$

alčak $m$ (tur. alčak) nevaljalac, mangup, prefrganac, vragoljan - I onaj halćak (lopov) malo se nasmije i pogleda u zemlju. (III,7,120), (II,6,120)

alem $m$ (tur. alem) dijamant - Velebna mis'o alemova sjaja, odsjev njezin vasionom spaja... (I,1,1), Dvadest ljeta, što na Tvojoj glavi, / Zlatna mitra rodu našem sjaji / I u mitri tri alema sjajna: / Tvog života djela veličajna... (I,3,37), (I,4,62), (I,11,197), (II,8,146), (II,11,205) i drugdje.

alka $\check{z}$ (tur. halka) manji obruč od kovine - Čim je halka na vratima dvorišta zakucala, a vrata se naglo otvorila, naglo je i ona onaj napisani listak u njedrice spremila... (III,7,109)

amanet $m$ (ar. emanet) ono što se ostavlja nekome na čuvanje - ... koji od velikoga Boga u pohranu svoju primiše najsvetiji i najuzvišeniji amanet, naime, dušu svoga djeteta... (I,2,24), (II,7,140), (II,11,205), (III,12,201) i drugdje.

aršin $m$ (tur. aršyn) zajednički naziv različitih mjera za dužinu Majka joj osnovala, navila, uvela i odpočela, a onda nju za stan sjela i dala čunjak u ruke, odrediv joj, koliko ima otkati aršina beza, dok se ona sa kćerkom iz sela vrati. (II,8,161), ... on gradi zapise duge od dva aršina (1 i pol metar) tko godj ih nosi, svakim se dobrom ponosi. (III,4,73) i drugdje.

asli pril. (ar. asli) sigurno, upravo, zaista, vjerojatno - Koza k'o koza, ona je hasli (možda) gjavliji hajvan, pa se svakuda vere - popela se na jedan okresan dub, te brsti mladu dubovinu. (III,4,71)

ašarija $\check{z}$ (tur. išaret fišegi) raketa, vatromet - U predvečerje palili se kriesovi $i$ ašarije se bacale u vis, a mužari neprestano gruvali. (II,8,166) avlija $\check{z}$ (tur. avlu) dvorište - Zaniela se u crne misli, te nije ni čula kako su se otvorila polagano njezina avlijska vrata $i$ kako je tiho pokucao i unišao u sobu siedi svećenik. $(\mathrm{I}, 3,52)$ 
azur $m$ (ar. azur) nebesko plavetnilo, ultramarin - boja, modrina Zar čarna opet pojavi se zviezda / Na azur-nebu prošlosti nam davne? / Zar slavulj-ptica prenula se s gniezda, / Da rodu priča uspomene slavne? $(\mathrm{V}, 12,185)$

babo $m$ (tur. baba) otac - Otac ga mazi, pa on materi okreše: ne ću eto, mene će babo braniti! (I,10,187), Ako kloneš - posvjetuj se s njima / Za tvog srdca kod njih melem ima, / Sladak melem iz babine ruke... $(\mathrm{II}, 11,205)$

badava pril. (tur. bad + hava) bez učinka, uzalud - Današnjim psovačim zabadava sve opomene, zabadava sve kazne, koje očito stižu ove ljude, ipak oni nastavljaju svoj posao. (III,1,8), (II,10,197) i na više mjesta drugdje.

bajagi pril. (tur. bajagy) tobože, kao da - Oni se drže bajagi načela kršćanstva, ali znadu cieniti i usvojiti tečevine novoga vremena, i prilagoditi se novom duhu. $(\mathrm{I}, 1,3)$

balčak $m$ (tur. balčak) dio mača u koji je usađeno sječivo - I navali četa na dušmane klete, / Na balčaku sjaju krunice im svete, / I pobjedi vraga... a za spomen svietu / Na razboju crkvu podigoše svetu... $(\mathrm{I}, 10,181)$

basamak $m$ (tur. basamak) stepenište, stepenice, stube - Strvne sluge bacile prosjaka / Kamenitih preko basamaka. Pred kapijom stade prosjak gol. (II,8,146) i drugdje.

bašča $\check{z}$ (tur. bahče) zemljište pored kuće na kojem se uzgaja povrće, cvijeće - Jednom sam sjedio za pivnim stolom u bašči (vrtu) u družtvu njeke obitelji sa dvjema malim djevojčicama. (II,3,54), (III,9,159)

baška (tur. baška) napose, odvojeno, rastavljeno, svako za se... - Jednim su rezana uda na obaška, počam od nožnih prstiju pak do stegana, i onda od ručnih prstiju do prsiju, i tako od cielog tiela ostajao samo osječak. (II,3,34)

baškaluk (tur. baskalik) odvojeno življenje - ... prije [smrti otac ga je] iskao, da se izpovjedi, a on ne htjeo otić po misnika - nego ga još ružio, pa bacio u baškaluk, tu je umro - bez svega: sad mu se ukazuje u vatri sjedeć, i goreć još mu se keseć ruga. $(\mathrm{I}, 10,192)$

bataliti (tur. batal) pokvariti, srušiti, upropastiti - Ma prije su slušali, a? - iz budžaka će siedi Ivan, a drugi begenisaše njegove rieči, - već danas obatališe se uz 'došlje', k'o oni ne poznaju ni Boga ni starijeg! $(\mathrm{I}, 10,187)$ 
bedevija $\check{z}$ (tur. bedevi - beduhin) kobila arapske pasmine, jak teretni konj - ... a veli, bijaše zor junak Ali beg, be nije ga bilo u svoj carevini, a što imadjaše bedeviju... ma... nije puno rastavila od Markova šarina. $(\mathrm{I}, 10,186)$

beg $m$ (tur. bej) plemićki naslov u Otomanskom Carstvu... - Da se u noći ne bi od šta prepala, spavala je s begovicom i begom u istoj sobi. (II,8,161) i drugdje.

begenisati (tur. begenmek) odobriti, odobravati, povlađivati - ... a drugi begenisaše njegove riječi... (I,10,187) Dragi moj kume, eto ja sam obišao tvoj novi stan i begenatim ti. Nuder mi kaži, ja mislim da te je zapao gotov, preko tri hiljade i po. (II,11,213)

beharati (tur. behar) biti u cvatu - Malo mu koja po glavi i bradi beharala, pa ne bi rekao, da bi mu ime djed priličilo, a ipak, bio je djed, $i$ to ne po izgledu, nego po drugom. (II,5,104)

belaj $m$ (tur. bela) nesreća, muka, jad, neprilika - ... pa od belajluka iz daljine vrisnu: 'A... a... a... braćo, kakav se ono po blatu valja'... (I,8,157), Medjuto belaj natenta jednoga dječaka, da uzme jedno pile u ruke, da ga na rukama bolje razgleda. $(\mathrm{V}, 3,46)$

beli pril. (tur. belli) sigurno, zaista - ... eto smo ih mi beli učili kako valja slušati, pa jok... (I,10,187)

bena $\check{z}$ (tur. ben) budala, luda, bedak - Od istog stabla Kainova bijaše ljudi gorostasnih pod imenom giganta, oholi, bednasti i veliki usilnici, po primjeru i današnjih usilnika, koji misle, da Boga i neima, a kamo li da im što može učiniti, kako i oni ludo misliše... (IV,3,39), Beno benasta! kriknula sestra sva izvan sebe i da će van. Al Mate skoči ko ris... (II,1,13)

berićet $m$ (tur. bereket) dobar urod, bogat prinos, dobra ljetina, izobilje - ... što imam najpošlje, ono malo zemlje u kršu, ali krš je krš, riedko da u njemu ima berićeta (obilnosti). Ponese, pa smetne, udri suša, odnesi vjetar, obi krupa i nema, pa nema... $(\mathrm{II}, 10,196)$ Opet vam velim, u srce to primite, pak će vami doista blago biti, jer će vas vaš otac nebeski sa svakom srećom i berićetom obdarivati... (V,6,96)

bešika $\check{z}$ (tur. bešik) kolijevka - I dobri mladić, umoran, zaprašen otirao rukom krupan znoj sa čela. I opet mu do ušiju dopre glas. A glas bijaše mek, nježan, sladak, sladji od glasa majke nad bešikom. (V,7,112)

bez $m$ (tur. bez) pamučno platno domaće izrade - Donesite čvrsta platna (beza) i jamite voska... (III,4,70), (II,8,161) 
bezbeli pril. (tur. besbelli) sigurno, zaista - Bezbeli, da ima o svakim čovjek, štogod pripovjedati... (II,3,50)

birdem pril. (tur. birden) odmah, odjednom - ... znao je svašta na ovome svietu, birdem (dapače) i šta car večera. (III,7,116)

borija $\check{z}$ (tur. boru) truba - ... čuje se dalje neg vojnička borija (trublja)... (I,12,223)

bostan $m$ (tur. bostan) vrt, bašča - U njeg cvatu tri ruže rumene, / U bostanu brižljivo gojene; / Sliče ruže ko cviet jedne grane, / Nerazcvale, već tek razpupane. (IV,2,27)

busija $\check{z}$ (tur. pusu) zasjeda - Odleže za kradju u hapsu i nikako se dozvati, - najpotlim dočeka iz busije nekog trgovca, ubije ga i oglobia sud ga odsudi na vješala. (I,10,187) (busen, reg. = žbun)

čališiti (tur. čališkan) raditi, truditi se, marljiv biti - Jozo se oslonio na Ivu, mladjega, ali i pametnijega, neka on sam čališi (nastoji) za obadvojicu, da čim prije zapise dobiju. (III,7,117), Svakako čališi (najstoj) da ti dade one rimske moći, koje fra Pile ima pa ih nosi nad bolestnika, i odma ozdravi. (II,12,243)

čara $\check{z}$ (tur. čare) spas, lijek, pomoć - Unidjem s Miškom u kuću, tamo stara kuharica, čara Mara, skupila se kod ognjišta, metnula ruke na oči ječi i ljuto plače. (II,4,87)

čemer $m$ stanje gorčine; gorčina, jad, tuga - Oko dakle velika je stvar, jer kako i u narodnoj pjesmi siromah prosjak jadikuje: 'mene vode tudje ruke', tako je potresljiva, da ti duh čemeri. $(\mathrm{I}, 4,64)$

česma $\check{z}$ (tur. češme) ograđen i ozidan izvor uređen tako da voda u mlazu slobodno pada - ... a po njima [sobama] se pusta svila zlatom prepletena prolila, prozračne i ukusnim finim česmam rashladjene, iz kojih je sama ružičasta voda sukljala, te podižući se u sitnu kišu opet se sva u dragocijenjene školjke slivala. (II,1,9)

čibuk $m$ (tur. čubuk) probušeni šuplji drveni štap... - Gusti dim iz čibuka vijao se u koloturima izpred njihovih očiju i gubio se je u ništavilo i mnogi sravniše ljudski život onom dimu i uzdahnuše nad svojim potomstvom, koje ne shvaća kratkost života i da ga valja dobro upotrebiti i koje ne zna, da ljudski život traje samo jedan čas, da čovjek započme umirati čim se rodi, prva grobna raka svakom nam je bešika! (I,7,139), (II,4,87), (III,7,117) 
čik $u z v$. (tur. čyk) poziv na rvanje ili neko natjecanje - Pop ih liepo čik na mejdan, ne na nož ni na pušku oli sablju, već na svetinju $i$ molitvu. (III,5,89)

čirak $m$ (tur. čyrakman) svijećnjak - On htjede, da svećenici budu po propisu sv. Pavla apoštola umjereni, čisti, triezmeni, milosrdni, ljubezni, znani u zakonu božjem i crkvenom, da su dostojni biti u sredini puka, kao svieća u čiraku, da mogu ljude podučavati, svojim znanjem, njihove pameti prosvjetljivati i svojim kriepostima srca puka na pobožnost pobudjivati. $(\mathrm{V}, 4,59)$

čivija $\check{z}$ (tur. čivi) drveni ili željezni klin... - Po tom spopadoh samu pušku s čivije, turnuh u nju oštar fišek, pa najopreznije otvorih vrata, a da se ne bi čulo moje libanje, na prstima sam gamizao, dok sam se izvukao pred kuću. (III,9,160)

čust prid. (tur. čust) hitar, givak, spretan, okretan - Gle - govoraše tihim glasom žena ugljareva - kako je njezino odielo čusto i kovrčasto, kako je izvezeno i šarovito. - Nu, nu, pogledaj rukave, -gle, molim te, kako su na njima naslikane ptičice. - A, ah. $(\mathrm{V}, 1,15)$

ćage $s$ (tur. kjagat, kjagyd) papir, hartija - ... poteže iz nutarnjeg, džepa u kaputu kolik za dva prsta širok četverouglast komadić ćageta... (III,7,125), (III,8,142)

ćebe $s$ (tur. kebe) pokrivač bez postave - Van iz ćebeta, prevarili smo popa! ali se drug ne diže. (V,7,113)

ćeif $\check{z}$ (tur. keijif) volja - Učitelju to nije baš išlo po ćeifu. (IV,4,50)

ćilim $m$ (tur. kilim) debela prostirka istkana u orijentalnom stilu Ne misli, djevojčice, da je sretan, tko šeće mramornim odajama po ćilimima svilenim! $(\mathrm{V}, 9,145)$

ćorav prid. (tur. kör) slijep... - Jedni vratili zajmeno, ali je naš sviet brate u tomu gluh i ćorav, kad ište, stotinu ih: lalo mile, zajmiš li mu, više ga ne vidjaš, s tog se pravo veli, kao što je fra Paško znao reć: Podaj rukam, pa traži nogam. (II,3,50), (I,12,221) i drugdje.

ćorda $\check{z}$ (tur. kard) turska zakrivljena sablja... - Navalila četa sa svih strana bjesna / Na kršćansku vojsku, a sred klanca tjesna / Svjetlucaju ćorde, junak redom pada, / Junak kroči naprjed, al' i mr' jet se nada, / Za krst častni past će i rado umr'jet će. / Al' prevrnut vjerom ne može i ne će... (I,10,181)

ćošak $m$ (tur. köše) istaknut, nadnesen dio kuće - Čula nekakav šušanj $u$ šljivi, što no granam zakrilila ćošu i prozor naše sobe. (III,9,160), Na 
sred sobe gola gvozdena postelja. na njezine četiri ćoše (ugla) gore četiri svieće - nad glavom mu veliki križ. (II,4,87)

ćulah $m$ (tur. külah) kapa od valjane vune - Znat će on, pošto je Musa jarca derao - hoće on, da se s carem bije - djelišanum, puknut će mu ćiferica (glava), pa će mu ostati pust ćulah. (II,10,197)

ćutuk $m$ (tur. kütük) panj, glupa osoba - Kad žito pozobaše, gle dječijeg udivljenja: skoči pievac na jedan ćutak, mlatnu debelim krilima, razkorači se, otegnu šijom, te grabovim grlom zaori svoju davoriju... $(\mathrm{V}, 2,32)$

dagara $\check{z}$ (tur. tagar) posuda u koju se stavlja žeravica... - Na dvoru puhalo, a po malo i snježilo, a stari Ilija prinio dagaru s vatrom, pa u odaji bijaše dosta toplo i ugodno. (I,10,186), (I,7,137)

daira $\check{z}$ (tur. daire) sabiranje i sazivanje džinova (demona) - Ima ih pa ga šalje i u Konjic k nekomu glasovitomu odži, koji svašta znade ko duboki mudrac, on skupi dajiru (sazove gjavle, nečiste duhove), ako ti on ne pomogne drugi neće, to mora biti s gjavlje strane. (III,4,73)

dernek $m$ (tur. dernek) sajam, zbor vašar, skup... - Bože moj, kod fra Paške vaviek dernek (puno svieta), ovi pita za ovo, oni opet za ono, to se znade, svaki ima svoju nezgodu. (II,3,50), Sunce svakud ogranulo, a oni pod Mosor, sa svih strana vrvi sviet, taman ko na dernek (trgovište), staro, mlado, ćoravo, sakato, ima ih i bolestnih, pa ih na konjim gone. (III,7,117)

divaniti (tur. divan) besjediti, govoriti, razgovarati... - Divanilo se i o ovom i o onom, dok će domaćin Ilija navrnuti govor na pravo, pa će... $(\mathrm{I}, 10,187)$

dolaf $m$ (tur. dolap) nepomičan ormar s policama, pričvršćen uza zid ili uzidan u zidu - Prvi put pred svetim ostacim (moćim) muke Isusove, koji se nalaze u dolafu svete Veronike... (II,1,16); Nikad prazan njegov dolaf (škrinjica)... (II,3,50)

dost $m$ (tur. dost) prijatelj - ... imat ćeš što čuti, bio moj veliki dost (prijatelj). (II,3,50)

dušek $m$ (tur. düšek) madrac - Ne dao joj se plač zastaviti, te ustane begovica i uzme je k sebi u dušek. Eto, tako su je pazili i milovali. Bog zna, koliko bi vremena i dokle u njih ostala, da joj ne poručiše svaku u Sarajevsko polje, kako je sramota i radi mrtva otca, da se ona savija po turskim kućama, gdje ostaje bez krsta, vjere i molitve. (II,8,161) 
džaba pril. (tur. džaba) besplatno, badava... - Zar, ti džaba guliš tabane, baš kao i ja ovdan. Vidim, bolje si plaćen, nego ja, u tebe sve sami žutaci dukati, a u mene samo koja pleta... (III,8,139)

džambas $m$ (tur. džanbas) prepredenjak, varalica - Ja ko stari džanbaš u tomu, odmah mu moju duhan kesu ponudim, u koju moj drug strpa svoju lulu... (II,3,49)

džebana $\check{z}$ (tur. džeba) municija, oružana sprema - Na putu pripoviedao šperac, kako se cesar bio s njekim drugim kraljem na moru, kako su oni potopili puno brodova $i$ svieta puno, zarobili silnu džebanu $i$ obranili zemlju od neprijatelja, a on sam bio tute vojnikom, $i$ to tako strašno i veliko pripovieda, da drugo niesu znali njih dvojica odgovoriti, već - Ahh a-ihh iiih. (III,7,116)

dželat $m$ (tur. džellâd) krvnik - ... na samotnoj obali rijeke Tibera dokončavaše se jedna žrtva. Liktori i dželati (krvnici) bijahu tamo dovukli povorku mladjih i starijih žena, kojima se je na licu neobično veselje čitalo. (II,7,136)

Džele Šanuhu $u z v$. (ar. galla šanuhu) uzvik kojim se popraća Božje ime - Znat će on, pošto je Musa jarca derao - hoće on, da se s carem bije - djelišanum, puknut će mu ćiferica (glava), pa će mu ostati pust ćulah. (II,10,197)

džezva $\check{z}$ (tur. džezve) metalna posuda s drškom za kuhanje kave Vrla stopanica Kata pristavila u odžaku džezvu - e, k'o na sielu, valjalo je popiti kahvu... (I,10,186)

džidža $\check{z}$ (tur. džidži) igračka za djecu, zvečka; imitacija pravog nakita - Liepe kose je najbolje dobro razplesti, očešljati, uplesti u pletenice $i$ oko glave jednostavno omotati ih, kako je u nas običaj niz ledja pustiti, ali ne vezati o njih kojekakve praporce i džidže, a pritom pako ne trebaš pomoći ničije, nego sama sebi možeš učiniti. (III,11,187)

džigerica $\check{z}$ (tur. džiger) jetra - Već je minulo 10 mjeseci, da je bio teško obolio u jetri (džigaricam). (V,9,146)

đemija $\check{z}$ (tur. gemi) lađa, brod - Sa svih strana svieta $k$ njemu dolazi i lipo priko mora u djemijam (lagjam, parobrodim) znadu za nj i u Amerikam (Americi). (III,5,88)

đerdan $m$ (tur. gerdanlyk) ogrlica - Kao mirisni oblak obavija tvoje tielo tanka biela oprava osuta šarnim cviećem, gjerdani bisera $i$ dragog kamenja svjetlucaju na labudjem ti vratu... (II,8,149) 
đulistan $m$ (tur. gülüstan) ružičnjak - ... a zlatna kosa prosula zlatne niti po legjima - izgledaš kao mirisna ruža iz firdusova gjulistana. (II,8,149)

eglendisati (tur. eglenmek) razgovarati - ... ta sgodniji je čovjek kad se malko pokriepi, lakše je onda inglendišati (zabavljati se u razgovoru). (III,1,13)

(e)vala $u z v$. (tur. ejvallah) tako je, (tur. vallah, vallahi) bogme, bogami; baš, e baš ... - Evala im, dobro su uradili, pecljivo odgovori F..., ja ne imam, da ih za što ukorim, reče i vrata mu u lice zatvori. $(\mathrm{I}, 8,153)$ Tko će to moje kućane uvjeriti, ne će, valah, da dušu pustim, ta oni su me i prije naćerali, da trljam od nemila do nedraga. (III,2,37), $(\mathrm{I}, 10,187)$ i drugdje.

fajda $\check{z}$ (tur. faide, fajda) korist - Tako su htjeli njezini roditelji. Ona se je opirala i protivila, i plakala i tužila se, ali nije bilo fajde. Oni bili zatukli čavo u glavu, pa puklo, kud puklo. Bog im prostio... ama niesu dobro uradili. (III,12,204), Nema hvajde duše gubiti, oni su mi bili namjesto otca i majke. Ja ih se kao takovih vazda sjećam s najvećom blagodarnosti... (III,7,125), (I,8,153), (II,1,10), (II,9,177), (III,8,135)

findžan $m$ (tur. findžan, fildžan) šalica za crnu kavu - U jednoj sobi igrali se momci i djevojke findžana i pjevali, a u drugoj sobi oko dagare posjedali stariji ljudi, pripoviedali o koječem, a najviše o starom vaktu. $(\mathrm{I}, 7,137)$

fišek $m$ (tur. fišek) patrona - Po tom spopadoh samu pušku s čivije, turnuh u nju oštar fišek... (III,9,160)

fukara $\check{z}$ (tur. fykara, fukara) siromašni svijet, sirotinja - Kad mu švabica znade pogadjati, neka mu pogodi bez novaca, to ona znade, gdje ima novaca u zemlji, i neka ih iskopa, a ne guli jadne fukare (siromahe) i bezplatno dobro čini svomu bližnjemu. (III,9,157), No talijanaškoj fukari nije bilo do mira, nego su zviždanjem napali na čestitog dostojanstvenika. (III,9,167)

gajtan $m$ (tur. gajtan) predena ili platnena vrpca... - ... svoje dukate dobro zavezao u voštenu kesu, pa na svileni gajtan objesio, o vratu, metnuo u njedra pod pas... (III,6,105)

gurbetluk $m$ (tur. gurbet) skitnja uz prosjačenje - ... tko bi se mogao nadati, da mogu gospoda doći u te haljine i taki gurbetluk (nevolju), ta izgledati, ko kakov naš kopač ili nadničar. (III,3,57) 
(h)ele(m) konj. (tur. hele) kako mu drago, kako već bude, bilo kako bilo - Ele, šta ću ti duljiti, kontali ga fratri najtežega na pari. (II,3,50)

hajvan $m$ (tur. hajvan) živinče, životinja - Ako se vas hajvan smakne ili bolest sama od sebe mine - i tomu je pomogao zapis. (III,9,155)

halaliti (tur. halal) oprostiti se uz blagoslov - Poruči mi fra Paško, moj brat, da odmah $k$ njemu dodjem, jer je težko bolestan, da se bratski halalimo. (II,4,87)

han $m$ (tur. han) konačište orijentalne gradnje... - 'Okreni se i priedji samo preko puta, eno ti veliki han', pokazujuć mi ga rukom. (III,7,126), Još ćeš ti nadam se jeftinije proći, nego odrasli ljudi. Handžija je vrlo pogodan. Ne precjenjuje ni čovjeka, koji ima, a kamo li da će precieniti jednog dječaka putnika'. (III,8,141)

handžar $m$ (tur. handžer) dug kriv dvosjekli nož - Hoću Rade - ona mu se klela: / I prije bih, ali niesam smjela, / Danas hoću, evo handžar ljuti / I odmah se do majke uputi, / U srdce ga majčici zadjeni, / Za amanet donesi ga meni, / Za uzdarje srdca materina / Privinut ću mojim te grudima / Drhtnu Rade, sgrabi handžar ljuti / Lahkim skokom k majci se uputi... (III,12,201), Nad glavom im prietiše handžari... (II,11,206)

haps $m$ (grč. hapto, tur. hapisane) zatvor - Više puta bude stavljan $u$ haps i na različite načine pedipsan, pa po tom višebrojnim kaznam podlegao je, pa radi toga isti njegovi drugovi zamrziše ga, dok napokon, radi velikih prekršaja vojne uprave i nemoralnog ponašanja, bude stavljen pod ozbiljni sud... (III,4,64) i drugdje.

haran prid. (grč. haris, tur. od ar. stid) vrijedan, valjan, čestit - Ljubeć svoje, u tudje ne tiči, i med braćom bit će vječnog hara... (III,2,39), $(\mathrm{I}, 2,22)$

harčiti (tur. hardž) potrošiti - Predbacio mu je, koliko je došle za njega poharčio, dočim susjed za svoga, ni treći dio. (IV,5,67)

hasniti (tur. haszon) koristiti - Njoj reći, i ako vidjaše, da ga voli, nije hasnilo, jer njezini roditelji morali su prvi rieč čuti. (II,12,232), Što hasni sva svjetovna dobra posjedovati, ako se ne imade ova nebeska, vječna dobra? $(\mathrm{V}, 4,57),(\mathrm{I}, 4,63)$

hasura $\check{z}$ (tur. hasyr) rogožina, prostirka od rogožine - Godine 1219. sv. Franjo sabire redovnike u samostan Porciunkula, da obdržaje drugu obću skupštinu, koju prozvaše sbor hasura, jer buduć se sabralo množtvo redovnika i ne moguć stati u samostan, biše prisiljeni od hasura načiniti prebivalište. $(\mathrm{V}, 1,8)$ 
hatar $m$ (tur. hatyr) ljubav, volja, želja - Niesu svi pisci plemeniti i pošteni u životu mnogi drugo čine i misle, a drugo pišu, mnogi za hator novca podaju komadu papira svoju dušu, čast i poštenje. (II,8,148), $(\mathrm{II}, 11,212)$

hava $\check{z}$ (tur. hava) zrak - Ma baš je tako - Nikola će - eno onomadne pošo malo da uhvatim have. $(\mathrm{I}, 7,138)$

hazna $\check{z}$ (tur. hazine, hazne) blagajna, riznica; blago - Svak veli, daj fra Paško, daj fra Paško, ko da je u fra Paške carska hazna (blagajna), a niko neće ono zajmljeno da vrati... (II,3,50)

hećim $m$ (tur. hekim) liječnik - Bio veliki ećim (liečnik), znao je od svake bolesti izliečiti, a kako i ne će, kad je znao svakoj travi ime i od koje je bolesti... (II,3,50)

hefta $\check{z}$ (grč. heptá) sedmica, nedjelja dana - Svake efte piše mu sam papa makar po jednu knjigu, u kojoj ga liepo pozdravlja... (III,5,88), (II,12,242)

hem konj. (tur. hem) i, a, pored toga, usto - Vidite, hem, brkat, hem bradat, pa da ste me i češće vidjali, zaboravi se, a kamo li ciglo jednom $i$ to uz put, a još, kad je to bilo, ja se slabo i sjećam. (III,7,123)

herav pril. (tur. egri) krivo, nakrivo - Ko što otac, tako i djeca na sebe crnu svilu udarili, klobučiće na hero, a o prsluk svaki po zlatan lanac objesio. (II,9,173)

hesabiti (tur. hesab) računati; misliti, smatrati - Daj malo prosjaku, Ciganinu, agi, fratru, caru, i potroši se, što ne bi ni esabio (mislio). (II,10,196), U što godj pogleda ima - živoga i mrtvoga, da nema konta ni esaba (bez mjere i računa), vazda više osvane, nego omrkne, ajde mu ti sad govori u torbu? (II,9,177)

hrsuz $m$ (tur. hyrsyz) lopov, kradljivac - Ne bilo djevojke u selu, koju zaprosio nije, dapače znao je istodobno i sa tri, četiri ašikovati. Pravi lopov, hrsuz, ništarija. Djevojke suj v e to znale, tako da u njegovoj odsutnosti znale bi ga u sprdnju uzimati... (II,12,232), (I,5,87) i drugdje.

hućum $m$ (tur. hüküm) presuda, suđenje - Šimun potuži komšiju na ućumet (sud) i odrede mu, - da plati junca njegov komšija. - jer se Šimun zakleo baš na sudu, da ga je njegov komšija ukro, - zaklao $i$ uzeo za meso 45 forinti. (III,9,156)

ibrik $m$ (tur. ibrik) bakrena posuda - Čulo se još, kako je neki drugi beg, kad je išla s ibrikom na vodu, nagovarao, da se poturči, a ona na to plakala i potužila svom begu... (II,8,161) 
ićindija $\check{z}$ (tur. ikindi) treća dnevna molitva po propisima islama Dan se uzimlje ili naravni od po noći do po noći, ili crkveni od predvečerja (ićindije) do sutrašnjega mraka. (II,3,58)

imaret $m$ (tur. imaret) javna dobrotvorna kuhinja - Turski imareti (kuhinje za siromake), koji većinom ovise o pojedinim džamijam, danomice nahranjuju do 80.000 siromaka. $(\mathrm{I}, 12,236)$

insan $m$ (tur. insan) čovjek, osoba - Hvala ti, Bože, svakakva ti ima danas isana (čeljadi) na ovome svietu, a najviše hrdjava... (III,3,57)

jabandžija $m$ (tur. jaban) stranac, tuđin - Tu se voze jabandžije (gosti, tudjinci), prijatelji - namirnici, putnici, prosjaci, i svak znade za Jozinu kuću... (II,9,177)

jafta $\check{z}$ (tur. jafta) grupa sela koja pripadaju jednoj manjoj općini - ... zar ne znaš da no spada pod Tasovčićku japtu... $(\mathrm{I}, 1,12)$

japundže $s$ (tur. japyndžak) vrsta kabanice, omotač, zavoj - Vidio sam da mi je od boli i glada umrieti u ovoj japužmi... (V,11,172)

jazuk $m$ (tur. jazyk) šteta - Bolan Ivo, taman je jazuk (šteta), što nisi i ti fratar, kad znadeš tako liepo pripoviedati i svjetovati! (III,8,141)

jok uzv. (tur. jok) ne, nije, nema - ... to je baš ono zlo, jedno kara, a drugo pogovara, jedno bije, a drugo miluje, jok, to ne valja! $(\mathrm{I}, 10,187)$, $(\mathrm{I}, 10,187),(\mathrm{III}, 4,71)$

kabuliti (tur. kabul) pristati na nešto, usvojiti nešto - Jozo se vratio kući kiseo i nezadovoljan - ne bi ukabulio, što ne nosi zapisa, da si mu osedlana konja poklonio... (II,12,242)

kadifa $\check{z}$ (tur. kadife) baršun, samt - On obiknut po gavanskoj sili, / A navičan kadifi i svili, / Pa smišljao, gdje, će para naći / Da bi moga starom stazom poći. (IV,2,28)

kahar $m$ (tur. kahyr) žalost, tuga, briga - Crven plamen nebo liže, / Narod bjesni, viče, kara, / Tu vojnici kroče bliže, / A tam' kuća red izgara. (V,10,149)

kail pridj. (tur. kail) sporazuman, spreman, voljan - Jeste li kail, a? $(\mathrm{I}, 10,188)$

kaiš $m$ (tur. kayiš) remen - Diete, dok je maleno, pa te nešto ne posluša, a ti za kajiš, da ga izmlatiš, a iz budžaka će stopanica: Nemoj Nikola! $(\mathrm{I}, 10,187)$

kalauz $m$ (tur. kylavuz) putovođa, vodič, poseban ključ kojim se može otključati svaka brava - Sluga posluša svog gospodara i ode 
premda u tudju zemlju, gdje drugog nema vodje ni kalauza do Boga svog... $(\mathrm{IV}, 10,150)$

kamdžija $\check{z}$ (tur. kamčy) jahački korbač - Ošine ga $i$ podbode kandžijom, prodrma ga, odkrije, a drug mu ležao uistinu mrtav; dočim je on sav drhtao u smrtnome strahu, da se to i njemu ne dogodi. $(\mathrm{V}, 7,113)$

kašika ž (tur. kašik) žlica - Plaču žene, nabrajajući stotinu nejednakih, i da će im ostati djeca bez kašike mlieka. Sada svak vidi, jest nešto nesreća je, pa bila ona u lievom kolu ili u desnom volu. (II,11,221)

katil $m$ (tur. katil) ubojica, krvnik - ... taman ko katil (ubojica) od ubijenog. (II,5,102)

kavga $\check{z}$ (tur. kavga) oštar sukob, svađa, prepirka - Na medjašici u njivi uz kuću bijaše trešnja, prije su je zajedno obirali i dielili, pa nikad kavge, a ove godine u malo da ne bi mrtve glave s te trešnje. (II,12,229)

kidisati (tur. iz grč. kindyneúo) žrtvovati, upropastiti, ne požaliti, pregorjeti - ... spomenike ne samo sviet na divnijim mjestim podigao, nego još ondje, gdje na njih zub zle godine kidisati ne može, naime u svojim srcim... $(\mathrm{I}, 5,88)$

konak $m$ (tur. konak) noćenje, jednodnevno putovanje - Moli prosjak - posmjeh bogataša / Uz zvek mukli napunjenih čaša / Ko da veli: skin mi se sa vrata / Sto konaka daleko ti vrata! $(I I, 8,146)$ Svi dreče od puste muke, ko kad im se užaren sindžir (lanac) objesi o vratu, da se nikakva hudoba ne smije blizu primaknuti, makar na sto konaka (sto dana hoda) blizu. (III,7,120), (II,12,224) i drugdje.

kovrdžav prid. (tur. kivircik) kuštrav, kudrav - ... kako je njezino odielo čusto i kovrčasto, kako je izvezeno i šarovito. $(\mathrm{V}, 1,15)$

kurtaristati (se) (tur. kùrtala) spasiti (se), izbaviti (se), osloboditi (se) nekoga - Vidio sam po deset na nekoj čeljadi, pa opet ne mogu, da se kutarišu (oslobode) od svojih nezgoda i muka. (III,1,14), (III,2,37)

mahala $\check{z}$ (tur. mahalle) dio grada, naselje, zaselak - I opet se skupiše na sielo u djeda Ilije Milića. Baš svi redom, koji i sinoćke bijahu, još dva, tri pribranija došla iz druge mahale. $(\mathrm{I}, 10,186)$

mal $m$ (tur. mal) imovina, imetak, stoka, blago - Je li ti potreba, izmamit ćeš mu oli para oli ljekarija, ili šta ti treba i što ti je drago; gdje sreća, tu i nesreća, gdje je mala, tu je i zijana (šteta). (II,3,51)

marama $\check{z}$ (tur. mahrama) dio ženske odjeće - Pošlje te knjižnikove propovjedi ostadoše svi nešto pokunjeni - jedni vele onako i nije 
drugčije, drugi opet ni najmanje ne vjeruju - sviet, ko sviet, ko će njemu mahrama (rubaca) natkati? (III,5,88)

marifetluk $m$ (tur. marifet) lukavština, šala, psina - E -umovaše Ilija - pa nije brate svemu ni tudjin kriv. Istina Bog, oni unieše njakih adeta i marifetluka, što ih mi ne imadijasmo, ama opet smo i mi krivi! $(\mathrm{I}, 7,138)$

maša $\check{z}$ (tur. maša) hvataljka za žar... - Sjednuv moj budući drug, te lulu svoju potegne iza vrata, zaviri u nju, potegnu maše, malo garnu, te će mi smijuć se: - Je li ti liep duhan, daj da prokušam... (II,3,49)

mehana $\check{z}$ (tur. mej + hane) gostionica - Na podne stigli sva trojica u jednu mehanu (birtiju, butigu, krčmu, kako li se sve ne zovu), tu bio jedan drugi čovjek taman od Mosora... (III,7,116)

mejdan $m$ (tur. mejdan) boj, dvoboj, duel - Pop ih liepo čik na mejdan, ne na nož ni na pušku oli sablju, već na svetinju i molitvu. (III,5,89)

melem $m$ (tur. melhem) ljekovit pripravak za vanjsku upotrebu - ... jeli ti muka, skokni do fra Paške, on za čas načini melem (ljekariju) $i$ eto te opet zdravijeg neg si bio. (II,3,51), ... uviek dobro pogodjenim duševnim liekom i melemom za rane i mane čovječje nutarnjosti. $(\mathrm{II}, 10,203)$

meteriz $m$ (tur. meteris, metris) opkop od zemlje, rov, šanac - ... što je prije moguće, još iz malenih nogu, biva dok još u kolievci zviezde hvata, i zlatne sanke sniva, morali bi se roditelji starati, da preteču ogromne meterze (nasipe) svakom zlu, onoj mladjahnoj duši postavljati... (I,3,40)

mosur $m$ (tur. masura) duguljast oblik koji nastaje topljenjem snijega na krovovima, ledenica - I mlinarova mlinica bijaše se ušutila, a slapovi na rječici bijahu se smrznuli, te višahu mosuri niz hridine poput greda, - sve bijaše tiho i mirno ciela narav, priroda bijaše u mrtvom snu, - nema sada naizmjeničkih posjeta, svak se bijaše zbog leda priliepio uz svoju peć. $(\mathrm{V}, 6,93)$

mukajet prid. (tur. mukajjed) zainteresiran, pažljiv, obazriv - Jednom ukrade majčin jedinak drugom djetetu pisaljku, majka je to saznala, pa ni prekoriti ga, a nekmo li opomenuti, drugom ukrade ovo, trećem ono, ele se djetetu oslaščalo krasti, mati ni mukajet, već ga i dalje mazi i miluj: Dobro, moje zlato! (I,10,187), Nadodju i milosrdne sestre, da ga pomalo spreme i nagovore na pokoru, ali on ni mukajet. $(\mathrm{V}, 10,158)$ - ni mukajet - obično znači: 'ni riječi' 
mukte prid. (tur. muft, müft) badava, besplatno - Šta mene briga, što oni mukte (uzalud) tupe zube, kad mi ništa učiniti ne mogu. (III,7,121) odžak $m$ (tur. odžak) dimnjak... - Vrla stopanica Kata pristavila u odžaku džezvu - e, k'o na sielu, valjalo je popiti kahvu... (I,10,186)

para $\check{z}$ (tur. od ar. bara) novac... - Jesi li čuo, kako meni opsova vjeru, kad mu ne dadoh para, a tebi ludu pamet, što mu toliko zlata sasu u džep i malo mu se činjaše, ta ko će lakomca napuniti, da si mu i sto dukata ponudio još bi koji put zaiskao. (III,8,139) i drugdje.

paša $m$ (tur. paša) naslov visokih vojnih i civilnih dostojanstvenika u Turskom carstvu... - ... stariji si, pa znadeš bolje varati; još i konja jašiš, k'o kakav pašalija. Ovo malo moje kukavice u sitnižu htjede mi ona babasta popina izmamiti. (III,8,139)

pazar $m$ (perz. bazar) kupovina i prodaja... - Kad bih ja i manje primao nego pop za zapise, ne bi ništa drugo radio, već zapise gradio, nu onda bi mi trebalo dati dušu na pazar (trgovinu), dosta novca, ali duša ode u pakao za vazda... (III,8,139)

pilav $m$ (tur. pilâv) gusto kuhana riža s pilećim ili ovčijim mesom... Sam naš car ima kabanicu, a svi ostali kukuljicu, pa da se oni kozar, jadna im majka, s molućem (velikom vlasti) izbiju. Mislio i Moskov našega cara dobiti, al je pokusao pilav, kad mu nije bio još varen!!! $(\mathrm{II}, 10,197)$

pusatli prid. (tur. pusat) oboružan - ... jedno plavo momče srednjega struka, ali dosta okoprčno - i on pusatli (oboružan): nož, velika puška dvocievka... (III,7,116)

rahat prid. (tur. rahat) zadovoljan, spokojan, miran, raspoložen... Sto mala i imanja za paru, kad čovjek nema svoga pravoga rahatluka (zadovoljnosti) u svomu srcu. (II,9,177), On se vrati u kuću te se učini rahat. $(\mathrm{I}, 10,191)$

refena $\check{z}$ (tur. herifane) zajednički trošak ravnomjerno raspoređen... - Još došlo novaca u kesu, nek ima, za potrebe i za revene (putnog troška). Može se tako trofiti, da ti nešto zapane na putu pod jeftinu cienu... (II,12,242)

sanduk $m$ (tur. sandyk) drveni kovčeg ili škrinja - Unidjosmo u sobu, otvorismo jedan sanduk (škrinju), nešto prtenila $i$ još štogod čoheno izderano... (II,5,102)

sebetli prid. (tur. sebep, sebeb) sretne ruke - Svakako treba, da fra Pile zapiše zapis - on je sebetli ruke (sretne). (II,12,242) 
seiz $m$ (tur. sejis) konjušar - ... išao s Omer pašom na Crnu goru, on bio seiz uz starog Ali bega Vileića, a veli, bijaše zor junak Ali beg... $(\mathrm{I}, 10,186)$

sepet $m$ (tur. sepet) koš od šiblja - Mlada, liepa Cerničanka prolazila mostom, noseći pun koš (krto, sepet) raznih stvari, što ih je na Rieci nakupovala. (V,7,114), ... a osobito joj živo u pameti ostalo, kako je negdje preko mosta izmedju Skoplja i Travnika drečala u sepetu, a jedan je od Arnauta, što su tuda išli, plašio, da šuti, jer će je inače baciti $u$ vodu. (II,8,161)

sindžir $m$ (tur. zendžir, zindžir) lanac - Svakako, dug ostaje dug, nikad mu ne će sindžir s vrata dok se god neoduži. (II,3,51), Sindžiri (lanci) mu na nogam i rukam zveče... (I,12,226), Vise na srebrenom sindžiru (lancu)... (III,1,13), (III,7,120)

sofra $\check{z}$ (tur. sofra) okrugli stol za kojim se jede sjedeći na madracima, stol za kojim se objeduje - Gospodski je obet priredio. / Svakim blagom sofru učinio. / Pa uz čašu skupocjena pića / Gostio se nad razkošjem pića. $(\mathrm{II}, 8,146)$

šajka $\check{z}$ (orjen.) naoružan riječni brod na vesla $-S$ toga hrli sad na lakoj šajci / K Zemlji svetoj, našeg Spasa majci... $(\mathrm{I}, 4,63)$

šalvare $\check{z}$.pl. t. (tur. šalvar) dugačke i vrlo široke hlače, nogavica skupljenih oko gležnja... - Još onakoga ne vidje Jozo u šarvaram (šarvalam), znao bi i misu i prodiku reći, kako je mudar, samo da je fratar. (III,7,116)

šešana $\check{z}$ (tur. šeš - šest) vrsta duge puške... - ... te vazda na vrat na nos za svojom vižladi, da često nije znao, kamo idje, pokraj samoga groblja više puta žurio iz svoje šešane ili golice, kad se je i sveta misa govorila, tako, da su sami misari to dobro mogli čuti. (I,12,221)

šiljte $s$ (tur. šilte) vuneni četverokutni dušek za sjedenje... - Na meko šiljte u pročelju sjede ujak, a ostali se poredaše oko njega i propitaše se bratski i kršćanski za zdravlje. $(\mathrm{I}, 10,186)$

taksirat $m$ (tur. taksir) nesreća, zla kob - Još mu koja žena ili cura neito kriomice šapće, pa mu turi u šaku pletu ili čarape i živu preporuku, neka i njoj donese lapis, ta svak ima svoju potrebu, svak je štono vele, duian taksiratu (nonadnjoj). (III,2,38)

taman pril. (tur. taman) ... upravo, baš... - Bolja našega oka domaćega [duhana] nego taman tri kile, ovoga ljutuma, što se gubice od njega prište. (II,9,176), Utaman mu tumačili dokle će doći, utaman mu sko- 
rašnje upropašćenje obitelji predočivali, za sve to nije on niti najmanje hajao. (II,8,151) i drugdje.

tapija $\check{z}$ (tur. tapu) ovjerena isprava o vlasničkom pravu na nekretnine - A ma kako, bolan ne bio, - odpovrnu Jozo, - vidiš da je tamam na mrginju, nije ni moja ni tvoja na samo, već obojice ujedno. - A jok - evo tapija, - a ti stisni pa uberi još, pa i crvljivu. (II,12,229)

tarhana $\check{z}$ (tur. tarhana) izdrobljeno tijesto na mrvice u obliku zrnaca i osušeno, od čega se pravi istoimena čorba - Kad čuje otac gvardijan svu tu čudnu taru, skanu i ne satkanu, da se je Jozo ipak sjetio, odkle ga je to čapa čapila. Vrlo mu bude drago ta njegova dobra odluka $i$ pohvali mu to posljedne, a živo pripeli, da se odsele čuva tudjega ko vatre. (III,9,158)

teferič $m$ (tur. teferrüdž) zabava i gozba u prirodi - Bez sumnje bijaše ovo prvi put, prva prigoda, da su dječica za malo časaka, u smihu $i$ teferiču, naučila se mnogim i koristnim stvarima. (V,9,143)

tefter $m$ (tur. defter, tefter) bilježnica, registar, protokol... - ... opet otvorismo drugi, tamo opet nešto, ko i u prvom, nekakvih kartušina, tefterina nekakve sitnarije, al para jok! (II,5,102)

tokmak $m$ (tur. tokmak) malj, bat... - ... popala ga voda, oznojio se, kao da najtežim tokmakom (maljem) tuče u najtvrdju živicu stienu, sve curkom znoj niza nj curi... (III,7,119)

trampa $\check{z}$ (tur. trampa) razmjena dobara bez novca - O sretnih nas ako u svih ljudi budu sve razmjene, kupovanja i prodavanja tako poštena, kao što je vaša današnja trampa bila poštena. $(\mathrm{V}, 8,124)$

tuč $m$ (tur. tunč) bronca - ... najmladji sudac od 12 sudaca vrhovnog papinskog sudišta čita glasno na vratim, zvanim od tuča (bronca), papinu bullu u latinskom i talijanskom jeziku. $(\mathrm{I}, 2,29)$

ulak $m$ (tur. ulak) glasnik, glasonoša, teklić - Ali poslati ulaci mu ne znadoše drugo kazati, nego da sam Esav idje susresti ga sa četiri stotine svojih oboružanih ljudi $(\mathrm{IV}, 12,180)$

vakat $m$ (tur. vakit, vakyt) kraće vremensko razdoblje - Nego, ljudi moji, od šta vakat, od toga vrieme, dobrahno je zanoćilo, valja i kući doći, pa ćemo se i opet što prije sastati... (I,7,139), (I,7,137), (II,10,196) i drugdje.

zaira $\check{z}$ (tur. zahire) hrana, namirnice - Ja ne grdim svetih rieči, najljepša zaira (jelo) može biti u koritu, pa tko će ju onda okusiti? (III,8,140) 
zejtin $m$ (tur. zejtin) maslinovo ulje, ulje uopće - Jedni nose popu nekakve male bočice, kao ljudski palac, nješto u njima žuto, rek bi, da je zejtin (ulje), što li je, nose nekakvu travku, koja nečim žestoko zaudara (miriše, vonja). (III,7,117)

zeman $m$ (tur. zeman) vrijeme u velikom odsjeku - Možda su pomagali zapisi u stari zeman (doba), dok nisu ljudi bili opaki kao sada, nu sada ne mogu pomoći. (III,4,72) On je držao kod sebe na školanju jednog dječaka, koji po zemanu izidje na glasu mudrosti isto kao i on. $(\mathrm{V}, 4,68)$

zera $\check{z}$ (tur. zerre) sićušni dijelić, trunčica - Opet kad zaklinje gusine na drveću - odmah se stanu komuštrati, pa u jednu zeru pocrkaju tako crve ili što drugo. (III,5,89)

zijan $m$ (tur. zijan) šteta, kvar, gubitak - Je li ti potreba, izmamit ćeš mu oli para oli ljekarija, ili šta ti treba i što ti je drago; gdje sreća, tu i nesreća, gdje je mala, tu je i zijana (šteta). (II,3,51) 